\title{
ANKRD26 wt Allele
}

National Cancer Institute

\section{Source}

National Cancer Institute. ANKRD26 wt Allele. NCI Thesaurus. Code C151925.

Human ANKRD26 wild-type allele is located in the vicinity of 10p12.1 and is approximately $134 \mathrm{~kb}$ in length. This allele, which encodes ankyrin repeat domain-containing protein 26, is involved in adipogenesis, appetite and platelet functions. Mutations in the 5 ' promoter region of this gene that result in increased expression are associated with autosomal dominant thrombocytopenia 2 . 